\title{
Electrooxidation of Hydrogen on Ni-Organic Metal Complex Catalysts in Acidic Media for PEMFCs
}

\author{
Rui Lin, ${ }^{1}$ Jinli Qiao,, ${ }^{2}$ Haiyan Zhang, ${ }^{3}$ Chunhui Cao, ${ }^{1}$ Jing Fu, ${ }^{3}$ and Jianxin $\mathrm{Ma}^{1}$ \\ ${ }^{1}$ Clean Energy Automotive Engineering Center \& School of Automotive Studies, Tongji University, Shanghai 201804, China \\ ${ }^{2}$ College of Environmental Science and Engineering, Donghua University, Shanghai 201620, China \\ ${ }^{3}$ School of Resource and Environmental Engineering, East China University of Science and Technology, Shanghai 200237, China
}

Correspondence should be addressed to Jinli Qiao, qiaojl@dhu.edu.cn and Jianxin Ma, jxma@tongji.edu.cn

Received 23 March 2011; Accepted 9 May 2011

Academic Editor: Zhenmeng Peng

Copyright (C) 2011 Rui Lin et al. This is an open access article distributed under the Creative Commons Attribution License, which permits unrestricted use, distribution, and reproduction in any medium, provided the original work is properly cited.

Novel organic metal complexes with $\mathrm{N}_{2} \mathrm{O}_{2}$ coordination structure which showed high hydrogen oxidation reaction were synthesized. The catalytic activity was found to strongly depend on the heat-treatment temperature and the structural properties.

\section{Introduction}

Proton exchange membrane fuel cells (PEMFCs) are considered to be one of the most promising future energy powers. Despite many efforts have been devoted to the development of PEMFCs, problems which need to be solved in terms of efficiency, power density, stability, and reliability still remain $[1,2]$.

It is well known that platinum $(\mathrm{Pt})$ supported on carbon black is normally used as the most active electrocatalyst for oxygen reduction and hydrogen oxidation reactions in PEMFCs due to its high catalytic activity and excellent chemical stability $[3,4]$.

Nevertheless, the widespread commercialization of fuel cell technology has been greatly hindered because platinum is expensive, and its estimated amount is too small to supply a huge number of fuel cell vehicles. Also, the current state of art for achieving active materials is far from sufficient due to the low utilization efficiency of Pt. It becomes more serious when high loadings are required on the cathode due to the sluggish kinetics of Pt [2,5-9]. These difficulties have created enormous interests in the search for less expensive, more efficient electrocatalysts as well as less loading of catalyst during the past decades. With respect to identifying alternative electrocatalysts, better substitutes such as Pt-free catalysts have been sought for more than a decade. Several promising candidates have been proposed in the past, such as oxides $[10,11]$, carbides $[12,13]$, Pd- $[14-17]$ and
Ru-based binary catalysts [18-23], macrocycles (porphyrin or phthalocyanine), and nonprecious metal catalysts [2427].

Though it is important to learn oxygen reduction reaction (ORR) properties of the catalysts, little is concerned for the materials that could replace platinum as the anode catalyst in PEMFCs since the requirements for good resistance to both $\mathrm{CO}$ and acid are difficult to meet for normal alloy catalysts.

Most recently, the tungsten carbide has been regarded as a promising candidate to replace $\mathrm{Pt} / \mathrm{C}$ catalyst because it has the same behavior and anticorrosion properties as the platinum catalyst. But it shows very low activity toward the hydrogen oxidation reaction (HOR) [28]. Except for tungsten carbide and Ir-based binary alloys [23], N-ligand organic complexes of simple molecules containing transition metal center would be the better choices over alloy or oxide catalysts in view of their cost and structural potentiality [14].

In this work, the possibility of constituting new electrocatalyst was pursued for HOR using N-ligand organic complexes containing transition metal center of $\mathrm{Ni}$ (II). The design of novel Pt-free catalyst could not only decrease the cost of catalyst for fuel cell, but also has the structure potentiality by changing the organic structure.

The physical-chemical properties of the catalysts were studied by transmission electron microscope (TEM), cyclic voltammetry $(\mathrm{CV})$, and linear sweep voltammetry (LSV) to provide more insight into the hydrogen oxidation of 


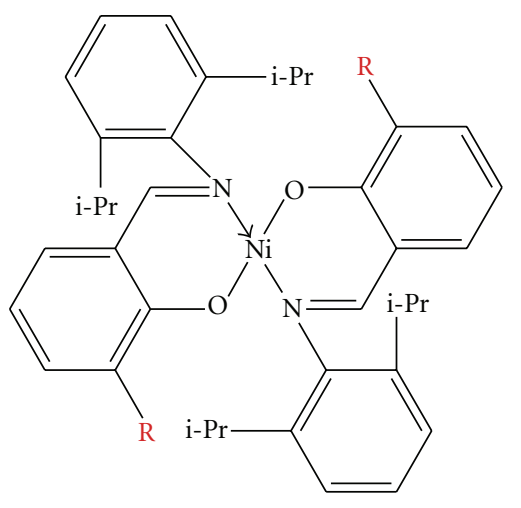

FIgURE 1: Chemical structure of organic metal complexes tested ( $\mathrm{R}$ $=\mathrm{H}, \mathrm{CH}_{3}$, and i-Pr, resp.).

$\mathrm{Ni}$ (bmdiph)/C catalyst. The results of characterizations and also their implications to the exploration of the nanoparticles as fuel cell catalysts were discussed. Emphasis was placed on the heat-treated temperature for the hydrogen oxidation catalytic activity of $\mathrm{Ni}$ (bmdiph)/C. Effects of the structural aspects of substituent on the metal complexes were also investigated.

\section{Experimental Details}

2.1. Catalyst Preparation and Characterization. Catalyst was prepared by depositing each organic metal complex, $\mathrm{Ni}$ (diph), $\mathrm{Ni}$ (bmdiph), and $\mathrm{Ni}$ (bidiph), respectively, with Vulcan XC-72 carbon black (Cabot Corporation, $S_{\mathrm{BET}}=$ $236.8 \mathrm{~m}^{2} / \mathrm{g}$ ) in ethanol in a mortar, and drying in vacuum at $40^{\circ} \mathrm{C}$ for $1 \mathrm{~h}$. Then it was processed by thermal treatment in an $\mathrm{N}_{2}$ atmosphere from $273-673 \mathrm{~K}$ for $2 \mathrm{~h}$ in a furnace with a heating rate of $20^{\circ} \mathrm{C} \mathrm{min}{ }^{-1}$, which was optimized for achieving effective catalysts.

The morphology of catalyst particles was observed by TEM analyses with a JEM 2010 EX microscope, at $200 \mathrm{kV}$.

Figure 1 showed the chemical structure of organic metal complexes, where $\mathrm{R}$ was $\mathrm{H}, \mathrm{CH}_{3}$, and i-Pr groups, respectively.

2.2. Electrochemical Testing. The electrocatalytic activities of the catalysts for the hydrogen oxidation were identified using a rotating disc electrode (RDE) by CV and LSV techniques. Two milligrams of $\mathrm{Ni}$ (bmdiph)/Vulcan XC-72 catalyst was suspended into $1 \mathrm{~mL}$ of methanol/Nafion solution $(50: 1 \mathrm{wt} \%)$ to prepare the catalyst ink. Then $10 \mathrm{uL}$ of the ink was transferred to a clean glassy carbon (GC) disk electrode ( $6 \mathrm{~mm}$ diam.). The amount of overall loadings of the mixed catalyst on the apparent electrode area of the GC disk $\left(0.283 \mathrm{~cm}^{2}\right)$ was $7.1 \times 10^{-5} \mathrm{~g} \mathrm{~cm}^{-2}$. Therefore, the current density reported here was all using the geometric area of the carbon electrode. For comparison, 40\% Pt/C (Johnson Matthey, JM) was measured at the same procedures.

The electrochemical HOR activity of catalyst was tested in a glass cell consisting of a three-electrode system in $0.5 \mathrm{M}$ $\mathrm{H}_{2} \mathrm{SO}_{4}$ at $25^{\circ} \mathrm{C}$, which was saturated with pure nitrogen in

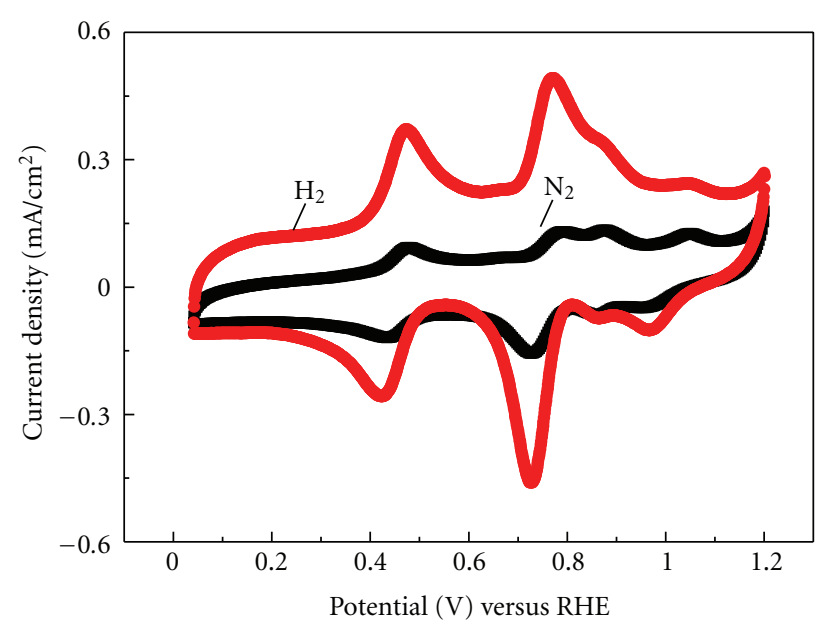

(a)

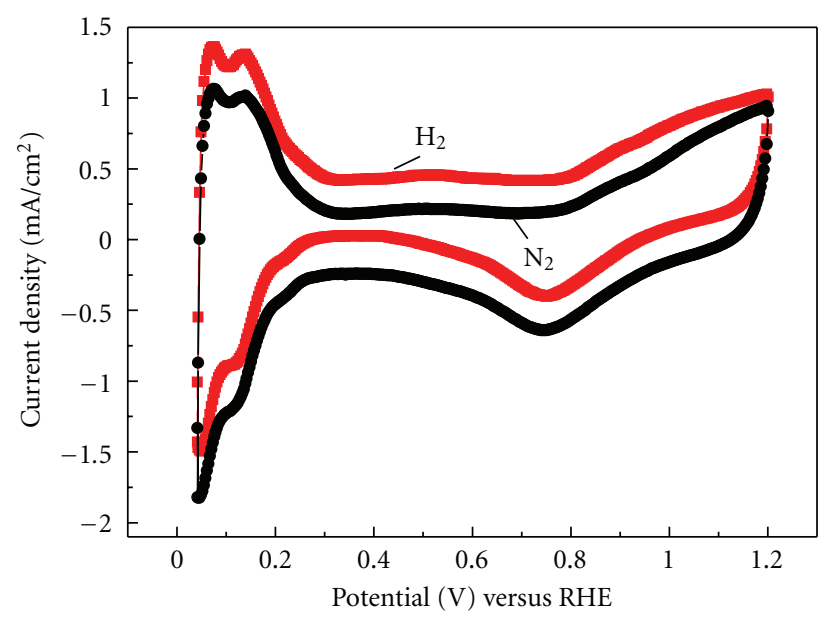

(b)

Figure 2: CV curves of a GC electrode coated with (a) $\mathrm{Ni}$ (bmdiph)/C (without heating) and (b) 40\% Pt/C (JM company), recorded in a $0.5 \mathrm{M} \mathrm{H}_{2} \mathrm{SO}_{4}$ (the solution was bubbled with (a) pure $\mathrm{N}_{2}$ and (b) $\mathrm{H}_{2}$, at a scan rate of $50 \mathrm{mV} / \mathrm{s}$ ).

order to expel oxygen in the solution. The saturated calomel was used as the reference electrode, and a platinum wire was used as the counter electrode. All potential in this work was referred to reversible hydrogen electrode (RHE). The measurements were carried out by using a rotating disk electrode (RDE, Pine 5908 Triangle Drive Raleigh, NC21617) by $\mathrm{CV}$ at $50 \mathrm{mV} \mathrm{s}^{-1}$ and LSV at $5 \mathrm{mV} \mathrm{s}^{-1}$, to determine the current density at room temperature in the $\mathrm{N}_{2}$ and $\mathrm{H}_{2}$ streams. Each electrolyte had been saturated with hydrogen for $30 \mathrm{~min}$ until the experimental system was stable before each HOR electrochemical measurement.

\section{Results and Discussion}

3.1. Activity of $40 \% \mathrm{Ni}($ bmdiph $) / \mathrm{C}$ towards HOR. Figure 2 compared the CV curves of the GC electrode coated with $\mathrm{Ni}$ (bmdiph)/C (without heat curing) and 40\% Pt/C (JM company), respectively, in the $\mathrm{H}_{2}$ - and $\mathrm{N}_{2}$-saturated $0.5 \mathrm{M}$ $\mathrm{H}_{2} \mathrm{SO}_{4}$ solutions. 


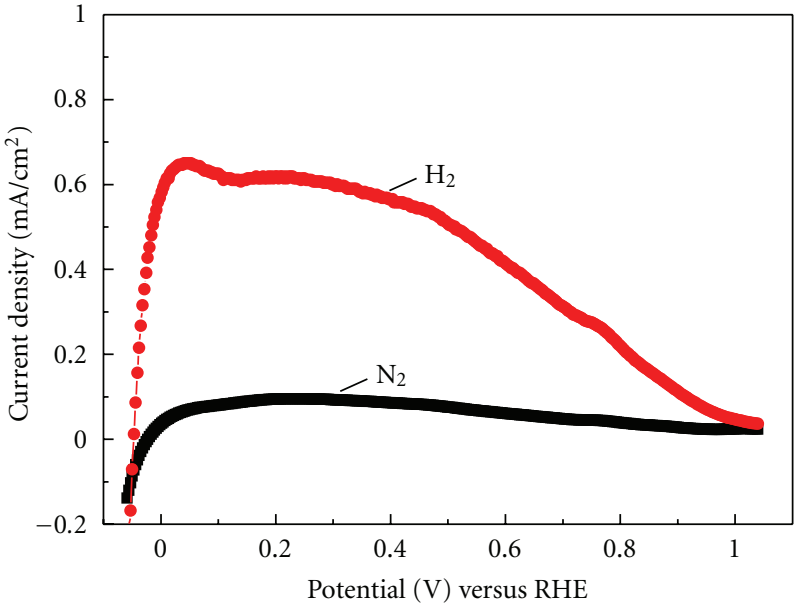

(a)

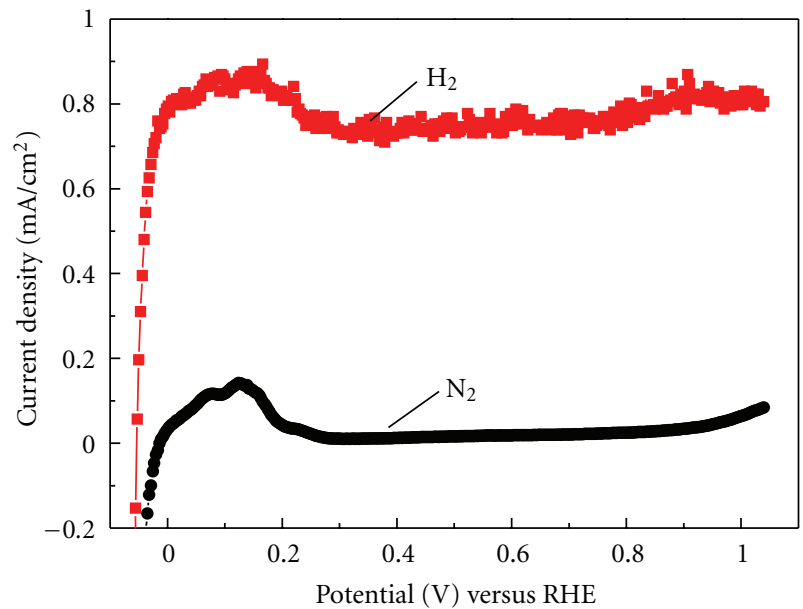

(b)

Figure 3: The LSV curves of $\mathrm{Ni}$ (bmdiph)/C (home-made, without heat curing) and 40\% $\mathrm{Pt} / \mathrm{C}$ (JM company) at rotation rate of $300 \mathrm{rpm}$ in $\mathrm{H}_{2}$-saturated or $\mathrm{N}_{2}$-saturated $0.5 \mathrm{M} \mathrm{H}_{2} \mathrm{SO}_{4}$ solution at room temperature.

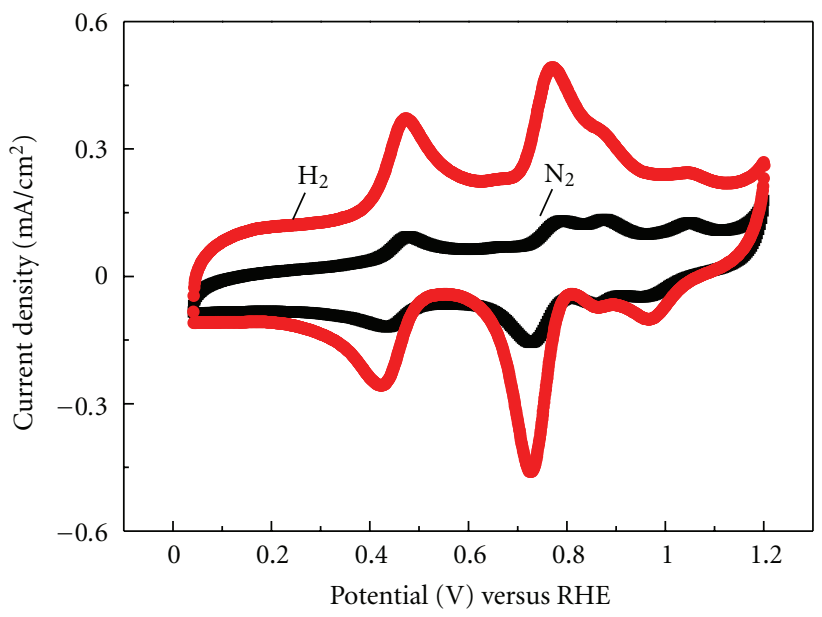

(a)

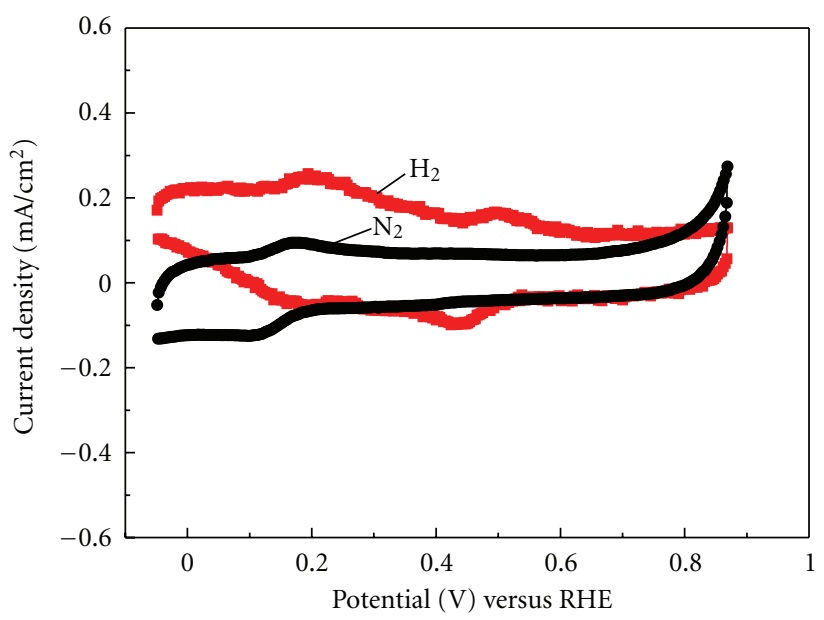

(b)

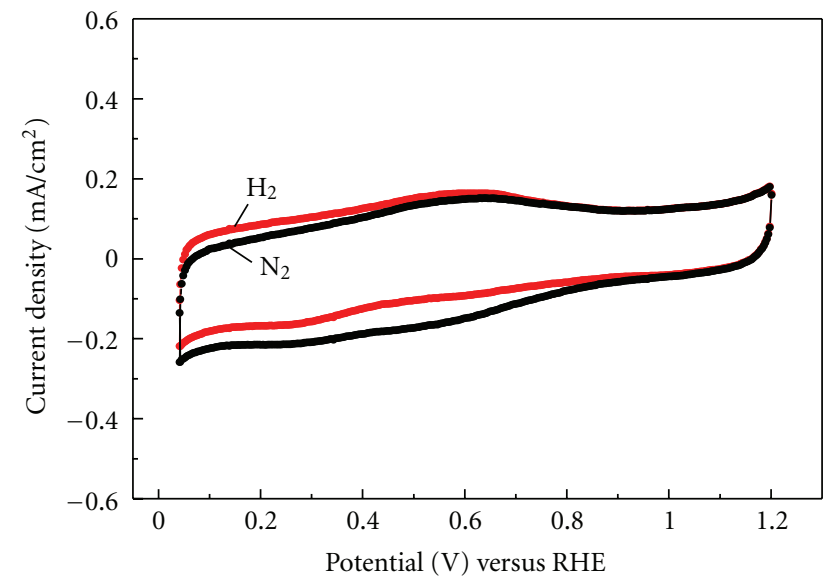

(c)

FIgURE 4: CV curves of $\mathrm{Ni}($ bmdiph $) / \mathrm{C}$ calcined at different heat-treated temperatures, in $0.5 \mathrm{M} \mathrm{H}_{2} \mathrm{SO}_{4}$ solution at the scan rate of $50 \mathrm{mV} / \mathrm{s}$. From the top to the bottom, (a), without heat curing, (b), $200^{\circ} \mathrm{C}$, and (c), $400^{\circ} \mathrm{C}$. 


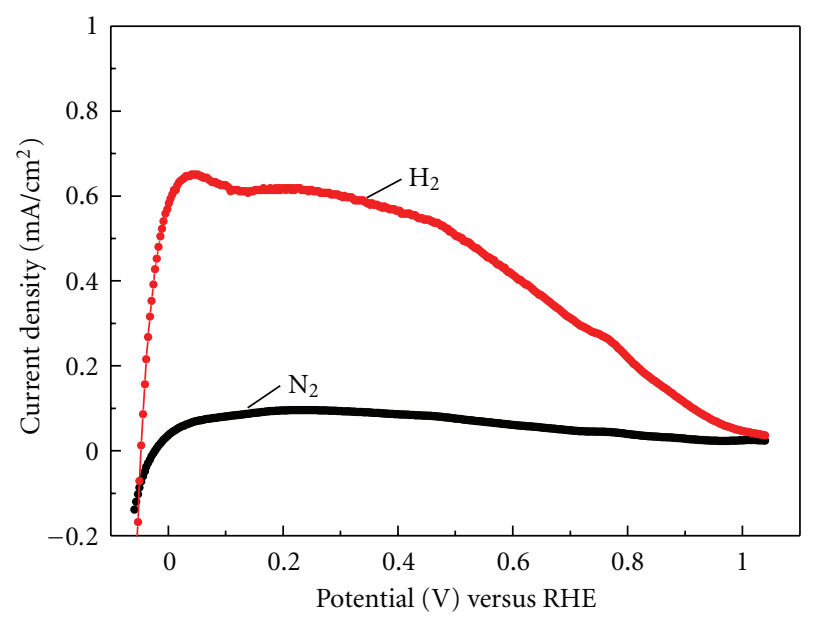

(a)

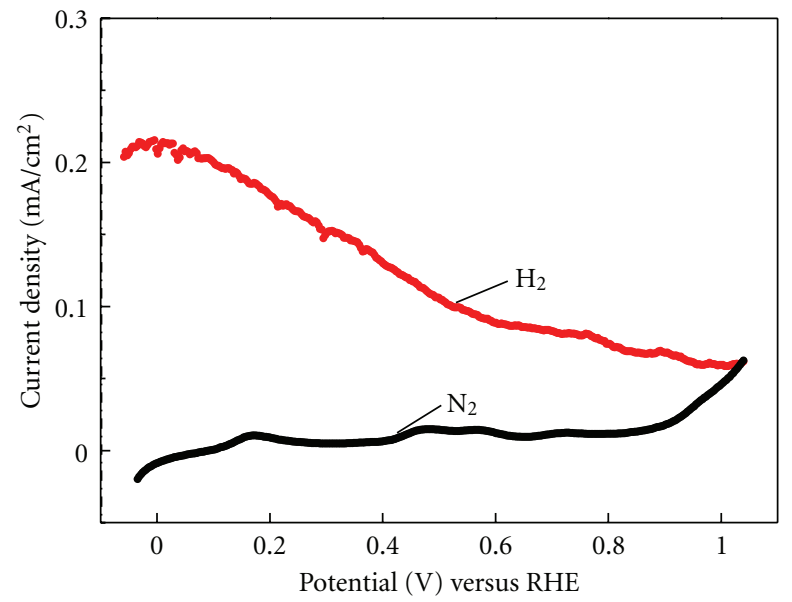

(b)

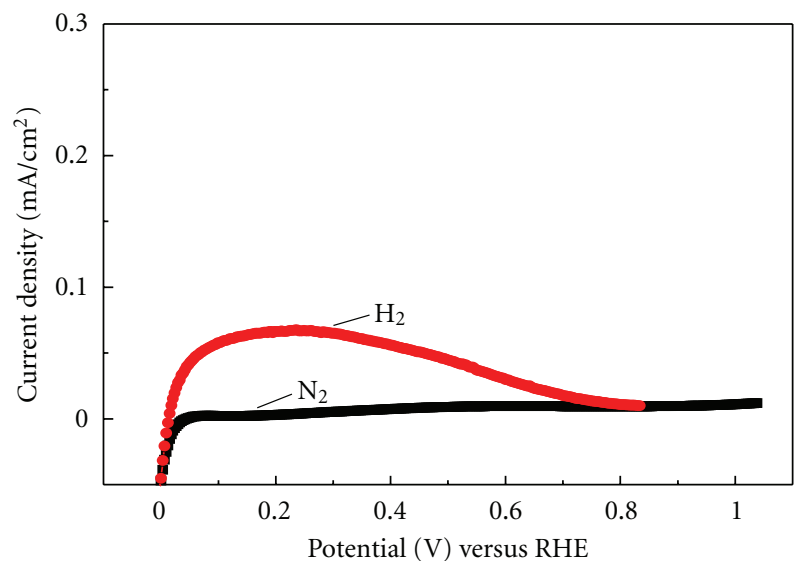

(c)

Figure 5: The LSV curves of $\mathrm{Ni}($ bmdiph $) / \mathrm{C}$ prepared at different heat-treated temperatures at rotation rate of $300 \mathrm{rpm}$ in $\mathrm{H}_{2}$-saturated or $\mathrm{N}_{2}$-saturated $0.5 \mathrm{M} \mathrm{H}_{2} \mathrm{SO}_{4}$ solution at room temperature, from the top to the bottom, (a), without heat curing, (b), $200^{\circ} \mathrm{C}$, and (c), $400^{\circ} \mathrm{C}$.

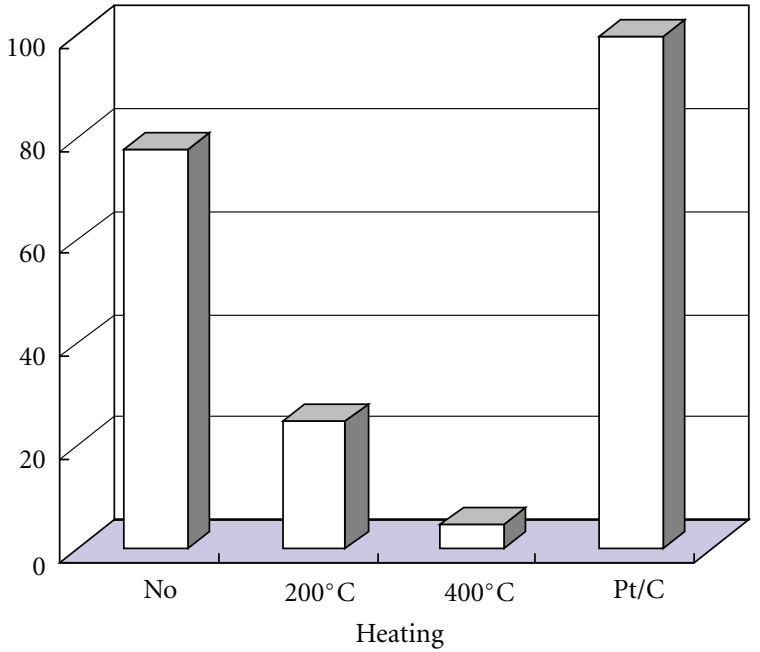

Figure 6: Relative current ratio of $\mathrm{Ni}$ (bmdiph)/C to Pt/C catalyst. 


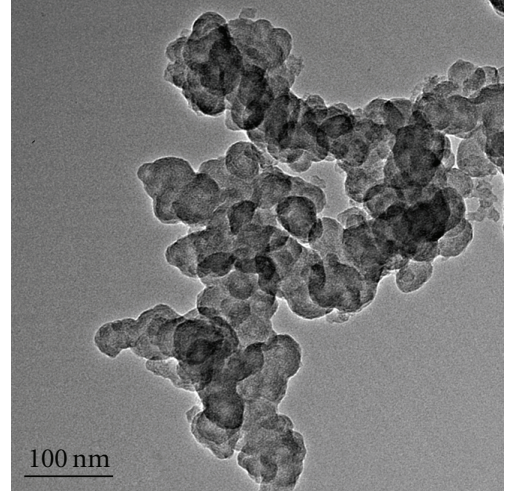

(a)

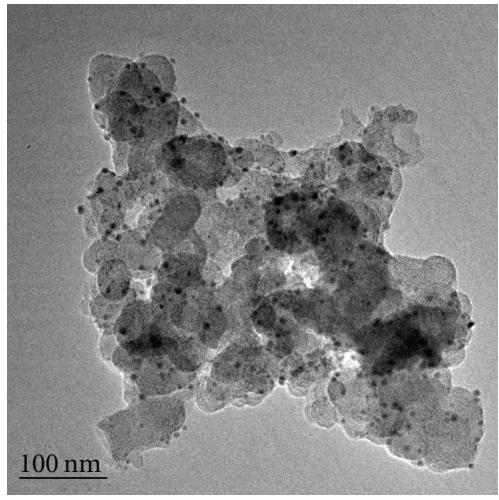

(b)

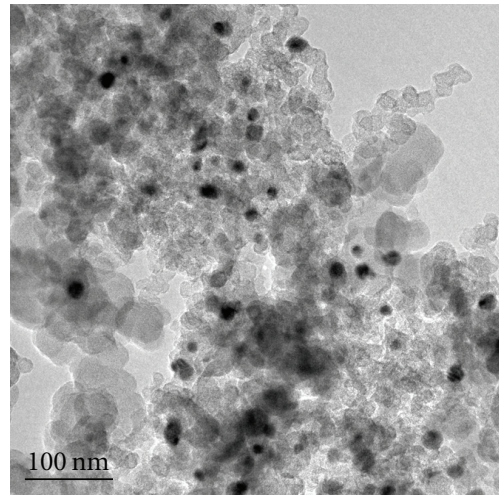

(c)

FIGURE 7: TEM images of the catalyst calcined at different temperatures, (a), without heat curing, (b), calcined at $200^{\circ} \mathrm{C}$, and (c), calcined at $400^{\circ} \mathrm{C}$.

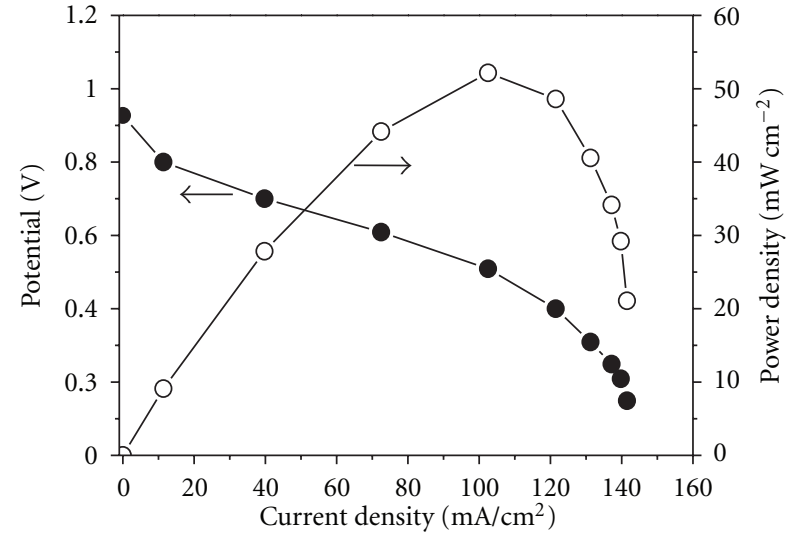

FIGURE 8: Cell voltage as a function of current density for single PEM fuel cells using $\mathrm{Pt} / \mathrm{C}$ catalyst as cathodes and $\mathrm{Ni}($ bmdiph $) / \mathrm{C}$ as anode, —-Potential $\bigcirc-$ Power density.

In Figure 2(a), it was noticed that in the positive scanning in $\mathrm{N}_{2}$ atmosphere, the current started to rise around $0.4 \mathrm{~V}$ versus RHE, and two reversible oxidation peaks were observed at about 0.45 and $0.8 \mathrm{~V}$ for the unheated sample, which were assigned to the $\mathrm{Ni}^{2+/ 3+}$ and $\mathrm{Ni}^{1+/ 2+}$ redox couples of the $\mathrm{Ni}$ (bmdiph)/C.

The oxidation peaks of $\mathrm{Ni}$ species in $\mathrm{H}_{2}$ atmosphere, which were assigned to the $\mathrm{Ni}^{2+/ 3+}$ and $\mathrm{Ni}^{1+/ 2+}$ redox couples of the $\mathrm{Ni}$ (bmdiph)/C catalyst at about 0.45 and $0.8 \mathrm{~V}$, increased obviously comparing with that in the $\mathrm{N}_{2}$ atmosphere. It indicated that the unheated $\mathrm{Ni}$ (bmdiph)/C had very good electrochemical activity towards hydrogen oxidation. Furthermore, the appearance of two redox couples suggested that $\mathrm{Ni}$ (bmdiph)/C might provide two different active sites for HOR, which will be discussed in the following section. Comparing CV curves of $\mathrm{Ni}($ bmdiph $) / \mathrm{C}$ with $\mathrm{Pt} / \mathrm{C}$ catalyst (Figure 2(b)), it was found, however, that the current density produced by the hydrogen oxidation of $\mathrm{Ni}$ (bmdiph)/C was still lower than that of Pt/C. It meant that the activity of $\mathrm{Ni}$ (bmdiph)/C towards HOR was still lower than that of $\mathrm{Pt} / \mathrm{C}$ catalyst.
Figure 3 displayed the LSV curves of $\mathrm{Ni}$ (bmdiph)/C (home-made, without heat curing) and 40\% Pt/C (JM company) at rotation rate of 300 r.p.m in $\mathrm{H}_{2}$-saturated or $\mathrm{N}_{2}$ saturated $0.5 \mathrm{M} \mathrm{H}_{2} \mathrm{SO}_{4}$ solution at room temperature. In Figure 3(a), a big difference between current densities which were, respectively, under $\mathrm{H}_{2}$ and $\mathrm{N}_{2}$ atmospheres was observed. Hydrogen desorption peaks were observed at the voltage between 0 and $0.4 \mathrm{~V}$, which could be attributed to the charge exchange during electroadsorption of $\mathrm{H}$ atom on the catalyst. A wide peak of current density of the hydrogen oxidation reaction can be observed, and its value reached to $0.65 \mathrm{~mA} / \mathrm{cm}^{2}$, which indicated a very high activity of $\mathrm{Ni}$ (bmdiph)/C towards HOR. In Figure 3(b), the peak of current density of hydrogen oxidation reached to $0.9 \mathrm{~mA} / \mathrm{cm}^{2}$ for $\mathrm{Pt} / \mathrm{C}$ catalyst at the voltage range of 0 and $0.2 \mathrm{~V}$. Comparing with the hydrogen oxidation activity of $\mathrm{Ni}$ (bmdiph)/C (Figure 3(a)), though the peak of the current density of $\mathrm{Pt} / \mathrm{C}$ catalyst was higher than that of $\mathrm{Ni}$ (bmdiph)/C catalyst, the range of current density of HOR peak of $\mathrm{Ni}$ (bmdiph)/C was wider than that of Pt/C. From the figures of LSV, it was found that the area of the desorption peaks of $\mathrm{Ni}($ bmdiph $) / \mathrm{C}$, which is at the range of $0 \sim 0.4 \mathrm{~V}$, was close to that of $\mathrm{Pt} / \mathrm{C}$ catalyst (at the range of $0-0.2 \mathrm{~V}$ ). The high electrochemical surface area and low cost were main advantages of $\mathrm{Ni}(\mathrm{bmdiph}) / \mathrm{C}$ catalyst, and thus it had the potential to replace the application of $\mathrm{Pt} / \mathrm{C}$ catalyst in PEFMC for hydrogen oxidation.

\subsection{Effect of Heat-Treated Temperature of Ni(bmdiph)/C to-} wards HOR. Figure 4 showed the CV curves of Ni(bmdiph)/ $\mathrm{C}$ calcined at different heat-treated temperatures, in $0.5 \mathrm{M}$ $\mathrm{H}_{2} \mathrm{SO}_{4}$ solution at the scan rate of $50 \mathrm{mV} / \mathrm{s}$. The cyclic voltammogram of all catalysts reached a steady state soon after the cyclic voltammetry started. However, the shapes of the cyclic voltammogram were based on the heat-treatment conditions. It was observed that the current density of $\mathrm{Ni}$ (bmdiph)/C was affected obviously by heat treatment temperatures. There were two oxidation peaks of the $\mathrm{Ni}$ (bmdiph)/C without heat treatment in $\mathrm{H}_{2}$ atmosphere, which were assigned to the $\mathrm{Ni}^{2+/ 3+}$ and $\mathrm{Ni}^{1+/ 2+}$ redox couples, 


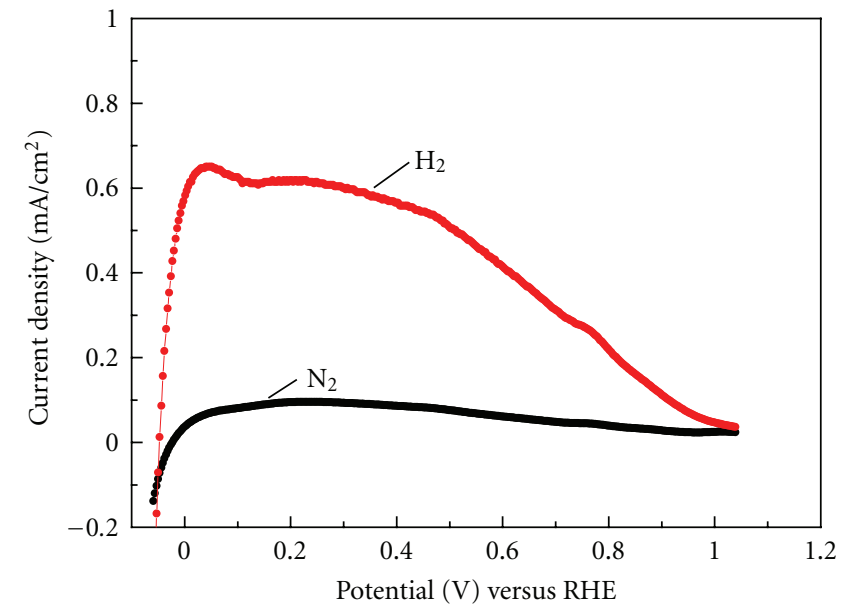

(a)

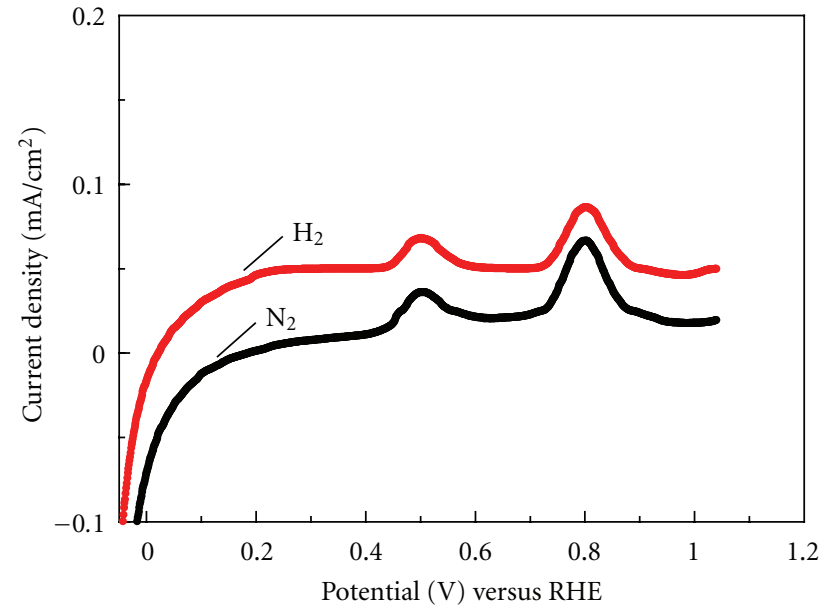

(b)

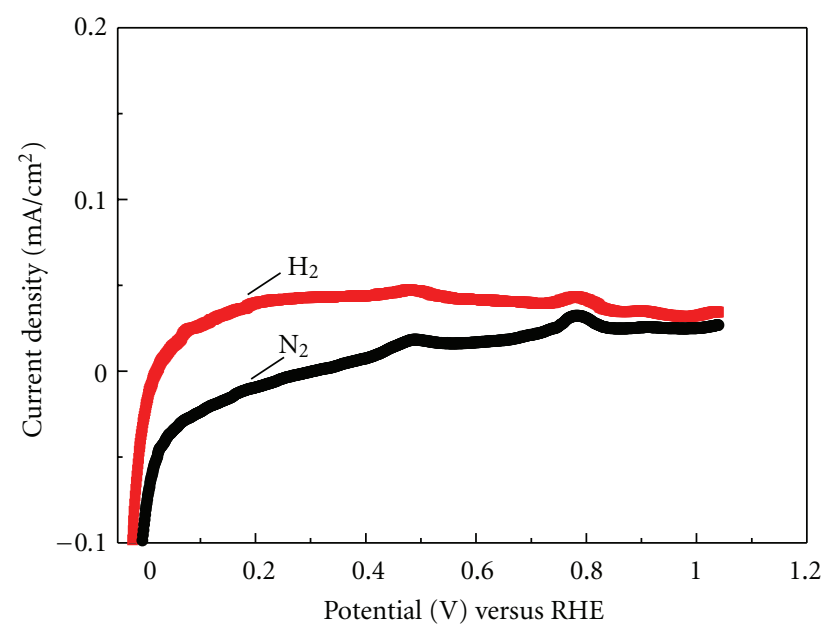

(c)

FIGURE 9: CV curves of Ni-organic metal complex with different substituent, in $0.5 \mathrm{M} \mathrm{H}_{2} \mathrm{SO}_{4}$ solution at the scan rate of $50 \mathrm{mV} / \mathrm{s}$. From the top to the bottom, the substituent was changed from $\mathrm{CH}_{3}$ - to $\mathrm{H}$ - and to i-Pr-.

respectively, at 0.45 and $0.8 \mathrm{~V}$ versus RHE. After heat treatment at $200^{\circ} \mathrm{C}$, the peak of current density around $0.8 \mathrm{~V}$ almost disappeared, and the peak at $0.45 \mathrm{~V}$ versus RHE drastically decreased. After heat treatment at $400^{\circ} \mathrm{C}$, both current density peaks at $0.45 \mathrm{~V}$ and $0.8 \mathrm{~V}$ versus RHE diminished.

It was clear that the higher the heat-treated temperature was, the lower the peak of the current density was. The unheated $\mathrm{Ni}$ (bmdiph)/C showed good electrochemical HOR activity, and the hydrogen oxidation peak around $0.5 \mathrm{~V}$ was much higher comparing with that of $\mathrm{Ni}$ (bmdiph)/C heattreated at $400^{\circ} \mathrm{C}$. It was clear that the activity of $\mathrm{Ni}$ (bmdiph)/C towards HOR decreased due to increasing heat treatment temperature.

Figure 5 displayed the LSV curves of $\mathrm{Ni}$ (bmdiph)/C prepared at different heat treatment temperatures at rotation rate of 300 r.p.m in $\mathrm{H}_{2}$-saturated or $\mathrm{N}_{2}$-saturated $0.5 \mathrm{M}$ $\mathrm{H}_{2} \mathrm{SO}_{4}$ solution at room temperature. The hydrogen oxidation peaks appeared around $50 \mathrm{mV}$. The current density peak decreased with increasing of temperature, which followed the same sequences of the CV curves. After treatment at $400^{\circ} \mathrm{C}$, the peak of current density decreased obviously to $0.05 \mathrm{~mA} / \mathrm{cm}^{2}$, which further confirmed that $\mathrm{Ni}$ (bmdiph)/C without heating-curing had the highest activity toward hydrogen oxidation.

Figure 6 compared the relative current ratio of $\mathrm{Ni}$ (bmdiph)/C catalysts (calcined at different temperatures) with $\mathrm{Pt} / \mathrm{C}$ catalyst (40\%, JM company) at the voltage of $50 \mathrm{mV}$ versus RHE. From the curves of LSV (Figure 5), it was found that the hydrogen oxidation activity of $\mathrm{Ni}$ (bmdiph)/C without heat curing was about $78 \%$ of that of $\mathrm{Pt} / \mathrm{C}$. We could also found that $\mathrm{Ni}$ (bmdiph)/C treated at $400^{\circ} \mathrm{C}$ exhibited the poorest electrochemical activity towards hydrogen oxidation among those catalysts. Its electrochemical activity was only $10 \%$ of that of $\mathrm{Pt} / \mathrm{C}$ catalyst. It was clear that the heat treatment of catalyst played important roles in the catalytic activity towards hydrogen oxidation as most metal complexes undergo thermal degradation above $200^{\circ} \mathrm{C}$ [29]. Therefore, it was very likely that the very catalytic activity after hightemperature treatment was due to the degradation of the metal complex. 


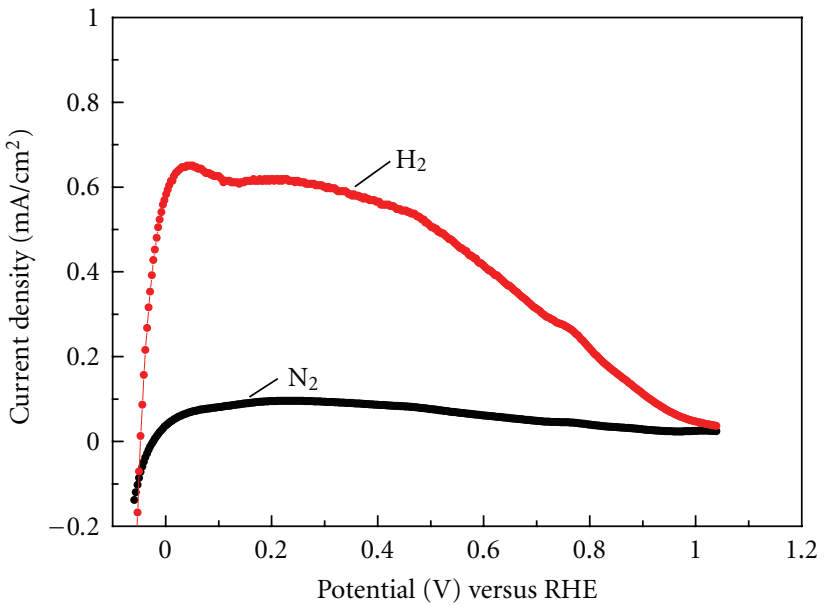

(a)

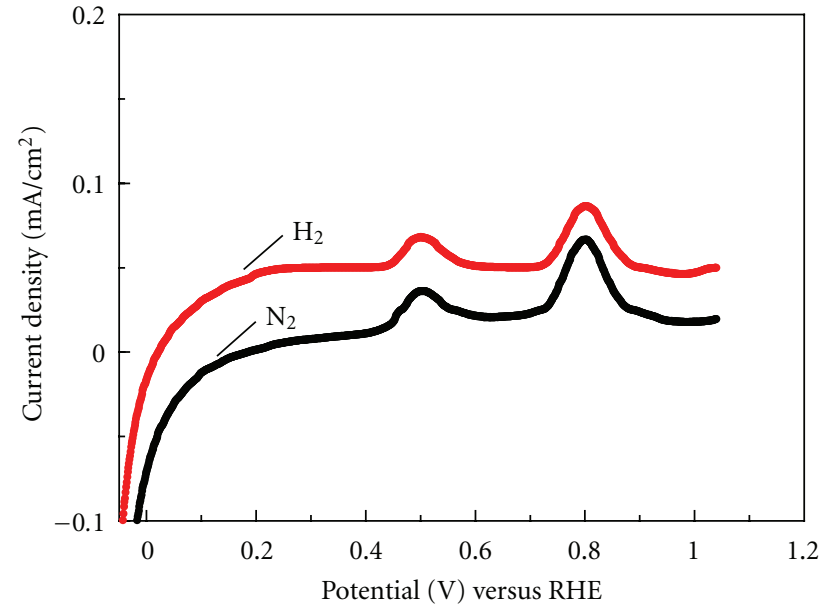

(b)

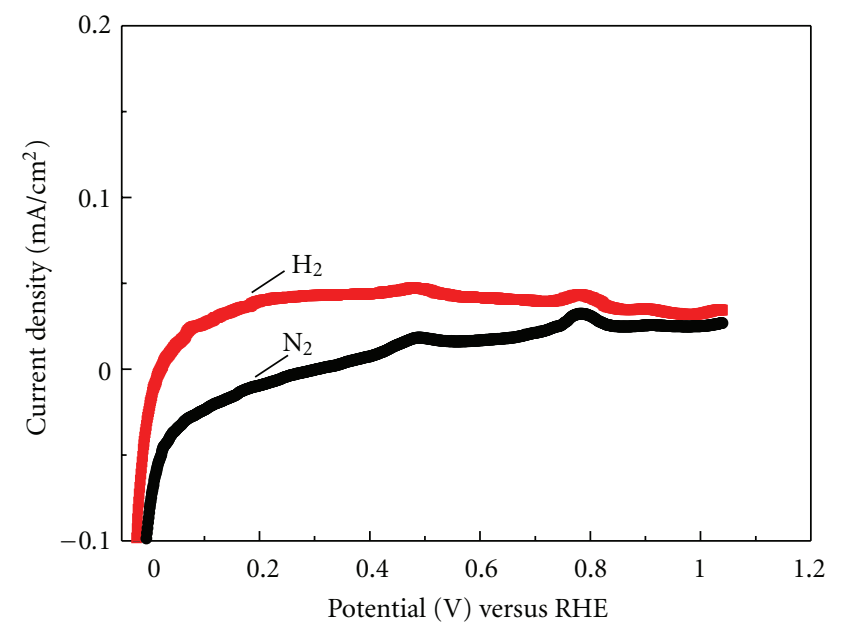

(c)

FiguRE 10: LSV curves of Ni-organic metal complex with different substituent, in $0.5 \mathrm{M} \mathrm{H}_{2} \mathrm{SO}_{4}$ solution at the scan rate of $50 \mathrm{mV} / \mathrm{s}$. From the top to the bottom, the substituent was changed from $\mathrm{CH}_{3}-$ to $\mathrm{H}$ - and to i-Pr-

3.3. Characterization of $\mathrm{Ni}($ bmdiph $) / \mathrm{C}$ Catalyst. Figure 7 showed the TEM images of $\mathrm{Ni}$ (bmdiph)/C catalyst calcined at different temperatures. It was found that $\mathrm{Ni}$ (bmdiph)/C without heat treatment uniformly dispersed on the surface of carbon support and the particles of Ni were close to spherical shapes with a mean particle size of $4 \mathrm{~nm}$. But after heat treatment, respectively, from $200^{\circ} \mathrm{C}$ to $400^{\circ} \mathrm{C}$, it was clearly seen that the particle size of catalyst obviously grew up, respectively, about $8 \mathrm{~nm}$ and $10 \mathrm{~nm}$, and also the aggregation of catalysts happened. It was clear the high-temperature treatment would lead to the easy aggregation of the catalyst particles. The sample without heat treatment is evidently smaller than the one after heat treatment.

High temperature could change the surface texture of active species and thus affect the catalytic activity toward hydrogen oxidation. $\mathrm{Ni}(\mathrm{bmdiph} / \mathrm{C})$ catalyst without heat treatment had small particle size (at $4 \mathrm{~nm}$ ), which was significantly smaller than the one calcined at higher temperature. This might be one of the reasons for the decreased performance of single fuel cell after heat treatment. The high-temperature treatment made the particle size of catalyst increase, and thus the active surface area of catalyst declined. That might be the reason for the increasing overpotential of the electrochemical reaction and thus the declining performance for hydrogen oxidation.

3.4. Single-Cell Performance. In order to investigate the catalytic performance of $\mathrm{Ni}$ (bmdiph)/C catalyst, member electrode assembly (MEA) based on the $\mathrm{Ni}$ (bmdiph)/C catalyst was prepared, and single cell testing was carried out.

Figure 8 showed the cell voltage as a function of current density for single PEM fuel cells using $\mathrm{Pt} / \mathrm{C}$ catalyst as cathode and $\mathrm{Ni}$ (bmdiph)/C as anode under a $\mathrm{H}_{2} / \mathrm{O}_{2}$ condition. MEA was fabricated with the $\mathrm{Pt} / \mathrm{C}$ catalyst in the cathode side at a loading of $0.5 \mathrm{mg} \mathrm{cm}^{-2}$ and $\mathrm{Ni}$ (bmdiph)/C at anode side at a loading of $0.5 \mathrm{mg} \mathrm{cm}^{-2}$. One can see that the opencircuit potential was around $0.94 \mathrm{~V}$. The active area of the fuel cell was $4 \mathrm{~cm}^{2}$. It achieved a power density of $52 \mathrm{~mW} \mathrm{~cm}^{-2}$ at $0.5 \mathrm{~V}$. Comparing with other reported organic metal complex catalysts, even though $\mathrm{Ni}$ (bmdiph)/C was almost at 
the same open-circuit voltage (OCV) values as that of $\mathrm{Pt} / \mathrm{C}$, the performance of single cell still needs further improvement. Through the optimization of the synthesis of organic complex and the MEA manufacture processes, the performance of $\mathrm{Ni}$ (bmdiph)/C will be improved. As the scarcity and the cost of Pt, completely or partly replacement of Pt by organic complex would be highly considered.

\subsection{Effect of the Substituent for Ni-Organic Metal Complex} Catalysts towards HOR. In order to investigate the structure effect on the organic metal complexes in more detail, substituent was changed from $\mathrm{R}=\mathrm{CH}_{3}$ to $\mathrm{R}=\mathrm{H}$ and $\mathrm{R}=$ $\mathrm{i}-\mathrm{Pr}$, which was corresponding to $\mathrm{Ni}$ (bmdiph), $\mathrm{Ni}$ (diph)/C, and $\mathrm{Ni}$ (bidiph)/C. Figures 9 and 10 were the CV and LSV curves of Ni-organic metal complex with different substituent. It was found that $\mathrm{Ni}$ (bmdiph) was much active towards HOR than that of $\mathrm{Ni}$ (diph)/C and $\mathrm{Ni}$ (bidiph)/C. The catalytic activity for hydrogen oxidation was in the order of $\mathrm{Ni}$ (bmdiph)/C $\gg \mathrm{Ni}$ (diph)/C > Ni(bidiph)/C. Although electron withdrawing effect of i-Pr group was larger than that of $-\mathrm{CH}_{3}$ and $-\mathrm{H}$, effect of steric hindrance of $\mathrm{i}$-Pr group was larger than that of $\mathrm{CH}_{3}$ - and $\mathrm{H}$-groups. It might be the main reason for the decreased activity of $\mathrm{Ni}$ (bidiph). Though the details of the hydrogen oxidation of organic complex were not yet clear and further investigation was needed, these facts suggested that the structure of the organic complex appeared to be a crucial factor for the HOR activity. Above results can be interpreted as a first indication that $\mathrm{Ni}$ (bmdiph)/C catalyst may be a very promising candidate for usage as the anode catalyst in $\mathrm{H}_{2} / \mathrm{O}_{2}$ PEMFCs. More detailed work on stability characterization and further improvement is going on to investigate the mechanism of the catalytic activity of Ni-complex oxides.

\section{Conclusions}

A novel nonnoble Ni-complexes $\left(\mathrm{Ni}-\mathrm{N}_{2} \mathrm{O}_{2}\right) / \mathrm{C}$ electrocatalysts have been successfully prepared in a flow $\mathrm{N}_{2}$ atmosphere. The carbon-supported catalyst displayed a strong activity towards HOR. The effects of heating temperature and substituent groups on its electrocatalytic properties were investigated. It was found that the activity of $\mathrm{Ni}$ (bmdiph)/C toward HOR was influenced obviously by heat treatment conditions and followed the order of without heat curing $>200^{\circ} \mathrm{C}>400^{\circ} \mathrm{C}$. $\mathrm{Ni}($ bmdiph $) / \mathrm{C}$ without heat curing was only about $22 \%$ inferior to that of a commercial $40 \% \mathrm{Pt} / \mathrm{C}$ (JM company). Substituent groups played important roles in the hydrogen oxidation activity for $\mathrm{Ni}$-organic metal complex catalysts. The substitution of $\mathrm{H}$-group by $\mathrm{CH}_{3}-$ group made $\mathrm{Ni}$ (bmdiph)/C exhibit the highest activity, while the steric hindrance of i-Pr-group might cause the decrease of electrochemical activity of $\mathrm{Ni}$ (bidiph)/C. The samples obtained were characterized by TEM. TEM results showed that the synthesized $\mathrm{Ni}$ (bmdiph)/C without heat curing had excellent dispersion of $\mathrm{Ni}$ particles on the carbon support while high-temperature treatment would lead to the easy aggregation of Ni particles.

\section{Acknowledgments}

This work was financially supported by Project Pujiang Foundation (no. 08PJ14096), Natural Science Foundation (no. 09ZR1433300) of STCSM, the Returned Overseas Chinese Scholars Foundation, National Natural Science Foundation (no. 20703031), "111 Project" (no. B08019), and Shanghai leading academic discipline project (B303).

\section{References}

[1] X. Yu and S. Ye, "Recent advances in activity and durability enhancement of $\mathrm{Pt} / \mathrm{C}$ catalytic cathode in PEMFC. Part I. Physico-chemical and electronic interaction between $\mathrm{Pt}$ and carbon support, and activity enhancement of Pt/C catalyst," Journal of Power Sources, vol. 172, no. 1, pp. 133-144, 2007.

[2] B. Wang, "Recent development of non-platinum catalysts for oxygen reduction reaction," Journal of Power Sources, vol. 152, no. 1-2, pp. 1-15, 2005.

[3] H. Wakayama, N. Setoyama, and Y. Fukushima, "Sizecontrolled synthesis and catalytic performance of Pt nanoparticles in micro- and mesoporous silica prepared using supercritical solvents," Advanced Materials, vol. 15, no. 9, pp. 742745, 2003.

[4] Z. Liu, X. Y. Ling, X. Su, and J. Y. Lee, "Carbon-supported $\mathrm{Pt}$ and PtRu nanoparticles as catalysts for a direct methanol fuel cell," Journal of Physical Chemistry B, vol. 108, no. 24, pp. 8234-8240, 2004.

[5] K. Shimizu, I. Francis Cheng, and C. M. Wai, "Aqueous treatment of single-walled carbon nanotubes for preparation of Pt-Fe core-shell alloy using galvanic exchange reaction: selective catalytic activity towards oxygen reduction over methanol oxidation," Electrochemistry Communications, vol. 11, no. 3, pp. 691-694, 2009.

[6] L. G. R. A. Santos, C. H. F. Oliveira, I. R. Moraes, and E. A. Ticianelli, "Oxygen reduction reaction in acid medium on $\mathrm{Pt}-\mathrm{Ni} / \mathrm{C}$ prepared by a microemulsion method," Journal of Electroanalytical Chemistry, vol. 596, no. 2, pp. 141-148, 2006.

[7] C. Jeyabharathi, P. Venkateshkumar, J. Mathiyarasu, and K. L. N. Phani, "Platinum-tin bimetallic nanoparticles for methanol tolerant oxygen-reduction activity," Electrochimica Acta, vol. 54, no. 2, pp. 448-454, 2008.

[8] Q. Huang, H. Yang, Y. Tang, T. Lu, and D. L. Akins, “Carbonsupported Pt-Co alloy nanoparticles for oxygen reduction reaction," Electrochemistry Communications, vol. 8, no. 8, pp. 1220-1224, 2006.

[9] R. Kothandaraman, V. Nallathambi, K. Artyushkova, and S. C. Barton, "Non-precious oxygen reduction catalysts prepared by high-pressure pyrolysis for low-temperature fuel cells," Applied Catalysis B, vol. 92, no. 1-2, pp. 209-216, 2009.

[10] J.-H. Kim, A. Ishihara, S. Mitsushima, N. Kamiya, and K.-I. Ota, "Catalytic activity of titanium oxide for oxygen reduction reaction as a non-platinum catalyst for PEFC," Electrochimica Acta, vol. 52, no. 7, pp. 2492-2497, 2007.

[11] J. Prakash, D. A. Tryk, W. Aldred, and E. B. Yeager, "Investigations of ruthenium pyrochlores as bifunctional oxygen electrodes," Journal of Applied Electrochemistry, vol. 29, no. 12, pp. 1463-1469, 1999.

[12] F. Mazza and S. Trassatti, "Tungsten, titanium, and tantalum carbides and titanium nitrides as electrodes in redox systems," Journal of the American Chemical Society, vol. 110, pp. 847850, 1963. 
[13] K. Lee, A. Ishihara, S. Mitsushima, N. Kamiya, and K. I. Ota, "Stability and electrocatalytic activity for oxygen reduction in WC + Ta catalyst," Electrochimica Acta, vol. 49, no. 21, pp. 3479-3485, 2004.

[14] L. Zhang, K. Lee, and J. Zhang, "The effect of heat treatment on nanoparticle size and ORR activity for carbon-supported Pd-Co alloy electrocatalysts," Electrochimica Acta, vol. 52, no. 9, pp. 3088-3094, 2007.

[15] V. Raghuveer, P. J. Ferreira, and A. Manthiram, "Comparison of Pd-Co-Au electrocatalysts prepared by conventional borohydride and microemulsion methods for oxygen reduction in fuel cells," Electrochemistry Communications, vol. 8, no. 5, pp. 807-814, 2006.

[16] J. L. Fernández, V. Raghuveer, A. Manthiram, and A. J. Bard, "Pd-Ti and Pd-Co-Au electrocatalysts as a replacement for platinum for oxygen reduction in proton exchange membrane fuel cells," Journal of the American Chemical Society, vol. 127, no. 38, pp. 13100-13101, 2005.

[17] M.-H. Shao, K. Sasaki, and R. R. Adzic, "Pd-Fe nanoparticles as electrocatalysts for oxygen reduction," Journal of the American Chemical Society, vol. 128, no. 11, pp. 3526-3527, 2006.

[18] R. G. González-Huerta, J. A. Chávez-Carvayar, and O. SolorzaFeria, "Electrocatalysis of oxygen reduction on carbon supported Ru-based catalysts in a polymer electrolyte fuel cell," Journal of Power Sources, vol. 153, no. 1, pp. 11-17, 2006.

[19] K. Suárez-Alcántara, A. Rodríguez-Castellanos, R. Dante, and O. Solorza-Feria, "RuxCrySez electrocatalyst for oxygen reduction in a polymer electrolyte membrane fuel cell," Journal of Power Sources, vol. 157, no. 1, pp. 114-120, 2006.

[20] V. I. Zaikovskii, K. S. Nagabhushana, V. V. Kriventsov et al., "Synthesis and structural characterization of Se-modified carbon-supported $\mathrm{Ru}$ nanoparticles for the oxygen reduction reaction," Journal of Physical Chemistry B, vol. 110, no. 13, pp. 6881-6890, 2006.

[21] T. J. Schmidt, U. A. Paulus, H. A. Gasteiger, N. Alonso-Vante, and R. J. Behm, "Oxygen reduction on RuMoSeO, Ru/carbon, and $\mathrm{Pt}$ /carbon in pure and methanol-containing electrolytes," Journal of the Electrochemical Society, vol. 147, no. 7, pp. 2620 2624, 2000.

[22] F. Dassenoy, W. Vogel, and N. Alonso-Vante, "Structural studies and stability of cluster-like RuxSey electrocatalysts," Journal of Physical Chemistry B, vol. 106, no. 47, pp. 1215212157, 2002.

[23] J. Qiao, B. Li, D. Yang, and J. Ma, "High PEMFC performance by applying Ir-V nanoparticles as a cathode catalyst," Applied Catalysis B, vol. 91, no. 1-2, pp. 198-203, 2009.

[24] R. Bashyam and P. Zelenay, "A class of non-precious metal composite catalysts for fuel cells," Nature, vol. 443, no. 7107, pp. 63-66, 2006.

[25] E. Claude, T. Addou, J.-M. Latour, and P. Aldebert, "A new method for electrochemical screening based on the rotating ring disc electrode and its application to oxygen reduction catalysts," Journal of Applied Electrochemistry, vol. 28, no. 1, pp. 57-64, 1997.

[26] J. P. Collman, P. S. Wagenknecht, and J. E. Hutchison, "Molecular catalysts for multielectron redox reactions of small molecules: the "cofacial metallodiporphyrin" approach," Angewandte Chemie International Edition in English, vol. 33, no. 15-16, pp. 1537-1554, 1994.

[27] H. Liu, C. Song, Y. Tang, J. Zhang, and J. Zhang, "High-surface-area CoTMPP/C synthesized by ultrasonic spray pyrolysis for PEM fuel cell electrocatalysts," Electrochimica Acta, vol. 52, no. 13, pp. 4532-4538, 2007.

[28] H. Chhina, S. Campbell, and O. Kesler, "High surface area synthesis, electrochemical activity, and stability of tungsten carbide supported $\mathrm{Pt}$ during oxygen reduction in proton exchange membrane fuel cells," Journal of Power Sources, vol. 179, no. 1, pp. 50-59, 2008.

[29] L. Odochian, A. M. Mocanu, C. Moldoveanu, G. Carja, and C. Oniscu, "Thermal degradation studies on some metal hydrazinic complexes," Journal of Thermal Analysis and Calorimetry, vol. 94, no. 2, pp. 329-334, 2008. 

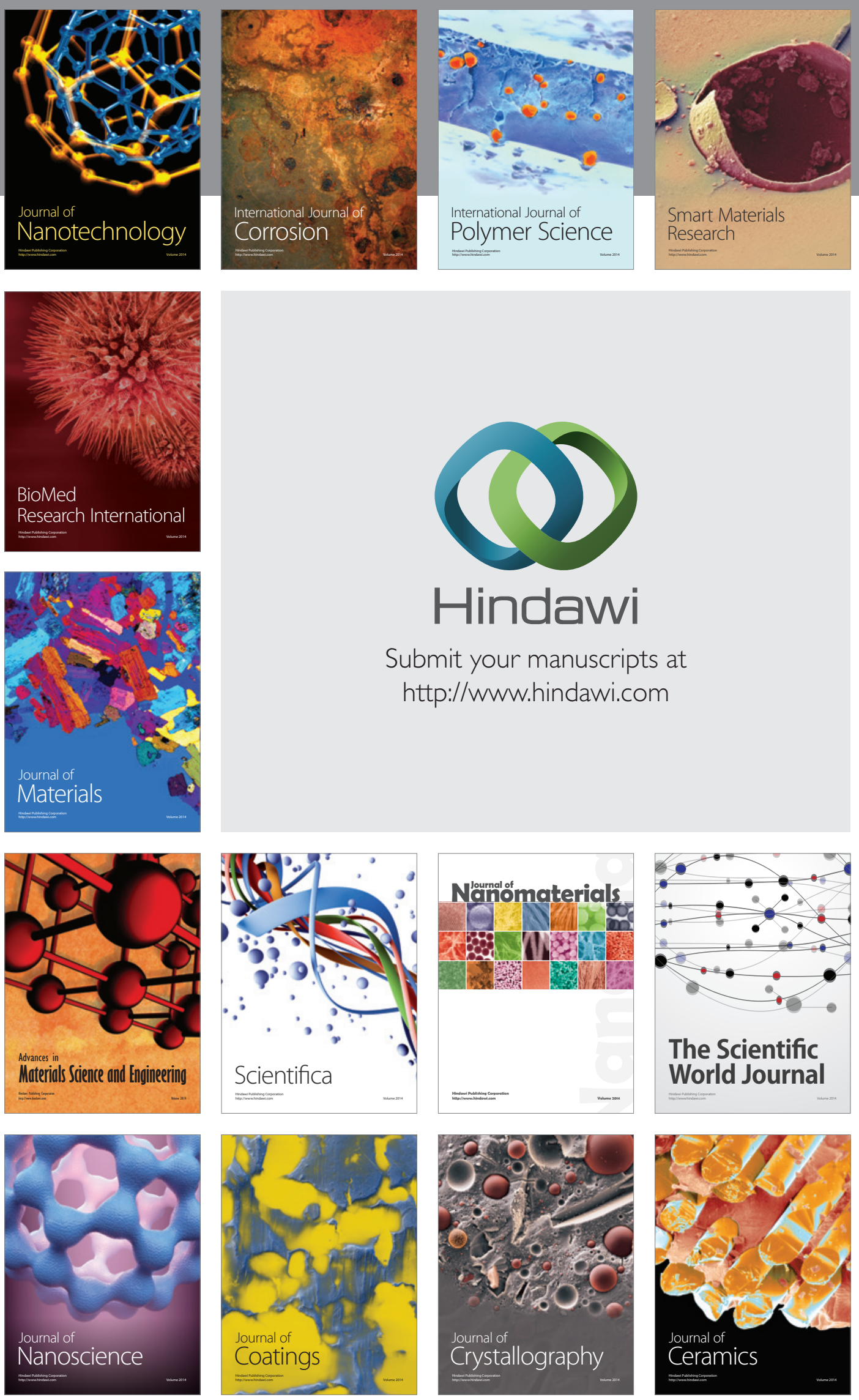

The Scientific World Journal

Submit your manuscripts at

http://www.hindawi.com

\section{World Journal}

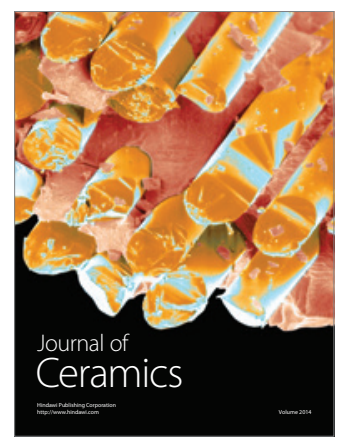

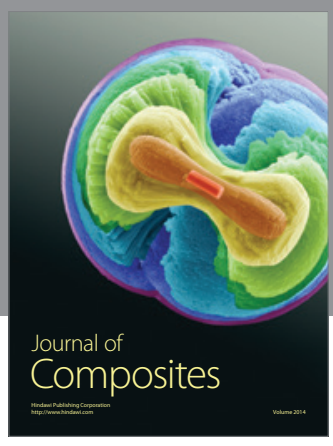
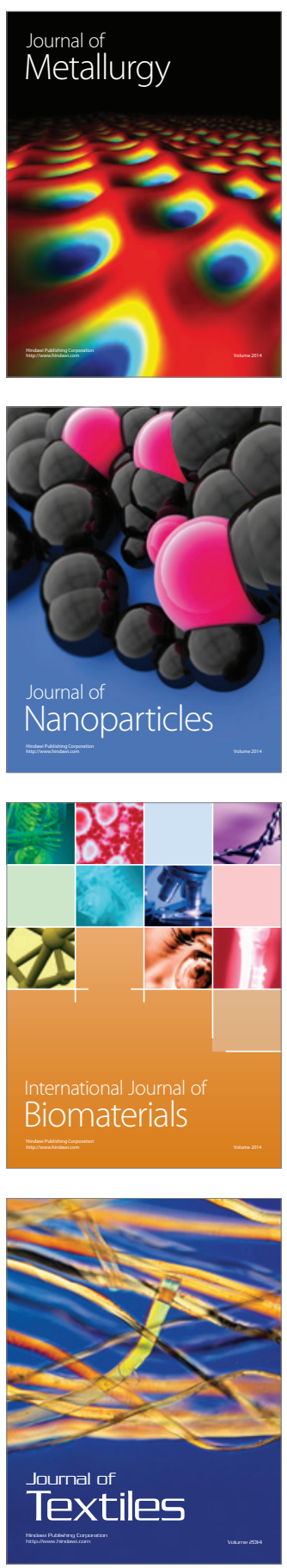